\title{
RELIGIOUS VALUES IN AN AGE OF GLOBALIZATION AND DEVELOPMENT IN NIGERIA
}

\author{
Cecilia Haruna Yahaya, Caxton Ayuba \\ Kaduna State College of Education, \\ Gidan-Waya, P.M.B.1024, Kafanchan, Nigeria \\ E-mail address: nkasiobisilasoguzor@yahoo.com
}

Keywords: Christian, religion, value, globalization and development.

\begin{abstract}
This write-up attempts to review the role of Christian Religion Studies and values in an age of globalization and development. This is because the world is undergoing a turbulent experience of war, civil unrest, national and international conflict and crises situation. Using the expository and deductive reasoning, the paper has found out that only religion and particularly Christian Religious Studies and education can use the values in its kit to overcome these challenges. These can be done through the framework of dialogue, respect for the plurality of religious faiths and good leadership. It provides a theoretical framework of the concepts of religion and globalization. It examines how Christian religious values become global and identifies the common Christian values and using such as indexes of globalization and development. It finally draws conclusion.
\end{abstract}

\section{INTRODUCTION}

The world is now becoming a global village, where people including those in the most remote parts of the world are increasingly interconnected, as though there is no distance between them. Globalization portrays a world that is borderless, where nations that are hundreds and thousands of kilometres apart from each other are now highly interconnected such that geographical distance between countries is of little or no consequence. Globalization therefore created the coming together of political, social, cultural, economic and religious factors driven by the development of information and communication technologies. It has increased interdependence and interconnectivity between different countries and cultures around the globe.

Christian religious values are of imperative necessity in the age of globalization and development. This is to facilitate the building of a free democratic society, where people will be conscious and highly organized to participate, promote and defend their hard earned democracy. The place of Christian values in the globalised world is to be appreciated if it assists in all aspects of national and international development. Nigeria and the world at large cannot have sound developmental activities without prioritizing its values. If Christian values are cherished and applied in the right dimension, then Nigeria will have a sound foundation or base for national and international development.

\section{CONCEPTUAL UNDERPINNINGS}

In order to provide the basis for this discussion, this paper will provide the definitions of Christian, religion, values, globalization and development. The understanding of such concepts would throw light on the understanding of a topic of this nature.

Religion: There is no one generally acceptable definition of religion as people look at religion from various perspectives. The content of that faith may differ from one religion to another. There will even be sharp differences of interpretation within the same religion. Oyeyinka \& Adeniyi (2005) pointed out that religion is a set of rituals by which the human relates with the higher being and also the effort by fallen man attempting to reestablish contact with his creator. This implies that religion is man's expression of his knowledge of the divine, a system of beliefs and practices 
relating to the sacred and uniting its adherents into a community such as Judaism, Christianity and Islam. Thus, religion has some powerful hold on a person's way of thought.

Ayuba \& Zakka (2007) pointed out that religion has to do with the whole human existence, and not merely with some special sector of it. Thus, religion is the whole 'complexes, attitudes, convictions, emotions, gestures, rituals, beliefs, and institutions by which express our most fundamental relationship with reality or God, the created order. Religion presupposes and flows from faith. It is an individual, social and institutional manifestation of some explicit faith in God. A religion without an element of the divine is like a house without foundation.

Therefore every nation and society has a claim to religion, which may depend on the sociological structure and climate of the 'being', since no one has been able to claim seeing God physically. From this perspective, religion can be seen as man's response to power, which seems to conduct him in his experience.

Globalization: Adamu (2003) saw globalization as a process whereby political, social, economic and cultural relation increasingly take on as global scale and which had a profound consequences for individuals' local experience and everyday lives. From this definition, it is clear that globalization relates to the process of growth of a phenomenon, within a native or peripheral unit or system of the universe into a phenomenon that exists in many or most or every units and system of the universe.

Usman (2004) defined globalization basically as the intensification of interconnection and interdependence between all parts of the world particularly at the levels of economy and communication. In other words, globalization refers to the relationship between all of us living this planet earth economically, socially, politically culturally and so on.

Christian: The word Christian etymologically comes from two Greek words "Christianos and Christos", meaning "follower of Christ" and "anointed one". It appeared three times in the New Testament Bible (Acts.11:26; 26:28, 1peter 4:16). The Bible tells us that "It was in Antioch that the followers of Jesus were first called "Christians". A Christian is one who professes belief in Jesus Christ or follows the religion based on the life and teachings of Jesus. In other word, a Christian is a person who adheres to Christianity; a monotheistic religion based on the life and teachings of Jesus of Nazareth, who Christians believe is the Promised Messiah.

Gotan (2005) stated that a Christian is a follower of Jesus Christ, that is, one who believes and practices the tenets of the Christian faith as presented in the Bible. The Christian is a person who believes in Jesus Christ, and whose whole life is shaped by that belief. Thus, a Christian is a social human person in whom God is present in grace but who is, at the same time, prone to act against the divine presence.

Values: Okpaga (2003) portrayed that values are the basis for the judgments people make as to what is desirable, correct and good, as well as undesirable incorrect and bad. In other words, values are issues regarded with esteem in the society. They are standards which serve as guide to what is acceptable to people. Values represent broad ideas regarding what is desirable, correct and good, that most members of society share. They enable society members to make evaluations regarding what is proper and what is improper and reprehensible. Values therefore serve as guide for socially acceptable behaviours.

Christian values: Christian values are ideals upheld by Christians. They can be considered to be standards which serve as guide to what is acceptable among Christ's followers. Christian values can also be described as set standards which serve as basis for evaluation of what is right and acceptable or otherwise, within the Christian religion. Christian values therefore make it possible for Christians to know what behaviours to display so as to be adjudged as Christians indeed, as well as what behaviours not to display in other not adjudged other wise.

\section{COMMON NATIONAL VALUES FOR GLOBALIZATION AND DEVELOPMENT}

Within the Nigerian body politics, there are ethical values enshrined in the Nigerian constitution. The Constitution of the Federal Republic of Nigeria of 1989, in section 23, page 31, stated that "the national ethics shall be discipline, integrity, dignity of labour, social justice, 
religious tolerance, self reliance and patriotism". The national ethics assert the relevance and the importance of morality to our cultural, social, economic, religious and political theories and practices. The national ethics are all moral principles which safeguard thoughts, behaviours, actions, and decision in various areas of our national life.

\section{CHRISTIAN RELIGIOUS VALUES IN AN AGE OF GLOBALISATION AND DEVELOPMENT}

What constitute Christian values is clearly spelt out by God through his prophets. These are found throughout the Holy Bible, itself. The followings can be identified as some Christian religious values to include:

- Respect for human life. Exodus 20:30

- Truthfulness. Exodus 23:1

- Reverence for parents. Ephesians 6:1

- Respect for the elders. Leviticus 19:32

- Love for one's neighbour. Matthew 22:39, John 13:35, Galatians 5:14.

- Sexual purity. $1^{\text {st }}$ Corinthians 6:8, James 2:11, Exodus 20:16

- Hospitality. Hebrew 13:2, $1^{\text {st }}$ Peter 4: 9, Leviticus 19: 34

- Peaceful living. Romans 12: 18, Hebrews 12: 14

- Obedience to constituted authority. Romans $13: 1,1^{\text {st }}$ peter 2:13.

The Christian ideals outlined above are just a few examples of Christian religious values. These values are numerous and cannot be exhausted in a paper of this nature. Guided by these values, a number of Christians have notably and positively impacted their societies. The pursuance of such Christian values as those of love for one another /charity and hospitality, Christian bodies in many countries including Nigeria have established such organizations as Motherless Babies' Homes and Orphanages, Home for the Aged, and similar institutions where needs of disadvantaged society members are catered for.

\section{VALUES SHARED BY CHRISTIAN RELIGION FOR GLOBALIZATION AND DEVELOPMENT}

Dzurgba (2002) in Ajeyet (2005) stated that values have several contextual meanings. Basically, they refer to worthiness, quality, importance and usefulness. Thus, values are those things we believe to be inwardly desirable or worthwhile. Christian religion is among the basic institutions and major force in influencing social behavior. There are certain Christian values that progressive to national development.

The following are Christian values that are jointly shared with the Nigerian national ethical values in her constitution: self-discipline, personal integrity, dignity of person, recognition of the worth of a person, social justice, respect for elders and people in authority, patriotism, respect for law and order.

\section{THE RELEVANCE OF CHRISTIAN RELIGION VALUES IN A GLOBALIZED WORLD}

Almost all religions can be global and transnational. They could organize people beyond national boundaries. The Christian churches and other religious and secular organizations are mobilizing people against its unhealthy influences. Today, a conflict between growing centralization and organization of power and wealth is in the hands of the few. It focuses on the differences, otherness, marginality, the personal, the particular, and the concrete over more general theory and politics that aim at more global or universal conditions.

Christianity as a religion has been globalizing. In the process of growth, the first primitive Christian church from Jerusalem vicinity expand into far flung gentile nations and then spreading to the rest parts of the world. Since then everything that is connected with human beings should be the concern of the Christian religions. Since then knowledge, language, religion and so on have all globalized throughout the time. 
The traditional religious geography has changed. Today, the "Christian West" and "nonChristian East" no longer exist. There are more practicing Christians in Asia and Africa than in the European countries. In the past the "West" used to send missionaries to the "East". Now the "East" is in a position to send missionaries to other parts of the world. The Arabian Middle East cannot be considered to be the largest Islamic concentration in the world. The largest Muslim nations are established in Asia. Hinduism and Buddhism, which start off on the Indian soil, have extended to almost every nation in the world. All countries in the world are pluralistic without choice.

Christian values can be relevant to anybody, anytime, any day and anywhere. The advanced media technologies serve as storage devices for messages and music containing Christian values. For example, it is often observed that Christian in Nigeria use Christian music or messages as ring tones for their cellular phones. It is also common to find them playing Christian messages or music with their personal computers while still working with the computers. These are all avenues of learning or being reminded of Christian values among Christians.

Cable and satellite television also play vital roles in spreading Christian values. There are countless cable and satellite television stations today which operate 24 hours every day, featuring Christian programmes. These include SCOAN, Love World, Dove Vision, ABN, Mercy TV, Miracle TV, DCLM, Chosen TV, DBN, Hope channel, Rhema, 3ABN, Kingdom life Network, CVV, Adonai, ACBN, CTV, and a myriad of others. These stations are not just operating on daily basis to broadcast messages, music, talk shows, documentaries and similar programmes which transmit Christian values, but these stations can be watched from different parts of the globe at the same time. Thus, someone in Nigeria can access and viewed a Christian programme in any country of Asia, America or Europe. There is no better way for people to acquire Christian values than through watching these Christian programmes.

In addition, Christians around the world are able to share ideas and views on issues via internet regarding their values through websites and emails. Time, distance and location are no longer serious barriers in disseminating Christian values at ease. Christian preachers like T.B. Joshua, Ayo Oritsejafor, Chris Oyakhilome, David Oyedepo, Reinhart Bonke, Joyce Meyer, T. D. Jakes, Benny Hinn, Kenneth Hagin, John Hagee and several others indigenous and non-indigenous ones have through the instrumentality of information and communication cables and satellite televisions become household names even though no physical contact with their viewers.

Giddens (2006) estimated that around a billion people were using the internet by 2005 . This number would probably have doubled by now. Unarguably, a significant proportion of the population of internet users are young people, Christian youths inclusive. The globalized information and communication technologies have become the major force inhibiting adherence to and practice of Christian values, especially among young people. These have been conquered by globalization.

\section{PITFALLS OF GLOBALISATION AND ITS CHALLENGES TO CHRISTIAN RELIGIOUS VALUES}

Globalization also poses a serious threat to the spread of Christian values. It is one thing for Christian values to keep on to be extended across the world, it is another thing for persons to imbibe and strictly adhere to them. Christian values can only make meaning and impact on people it is when they adhered to them, to the extent that they manifest in their behaviours.

Globalization facilitates the removal of barriers among nations of the world, thereby giving social relations unhindered access. The unique characteristics of globalization often includes increased capital mobility, decline in costs of transportation, computing and communications. Rodrik (1997) opined that globalization has been used rather loosely to stand for a variety of things: the shrinking of the world into a global village, the awesome changes brought about or mandated by the revolution in information technology, the collapse of boundaries between different worlds, expanding connectivity of all forms of interaction.

Daudu (2007) agreed with Oladimeji (2003) that since the inception of this present democratic dispensation, there were unprecedented civil disturbance and social insecurity resulting massive 
destruction of lives and property. Nigerians are battling with hunger, greed, selfishness, avarice, concupiscence, bribery and corruption. If Christian religious values were to become global and transnational; they stand to eliminate these threats and building a new humanity beyond national boundaries.

More dangerous dimensions of the digital revolution include pornography, money laundering, cultism, international terrorism and child abuse, which all constitute a threat to Nigeria and African cultural heritage. It is extremely problematic for African countries with strong Islamic and Christian cultures to tolerate the level of pornographic activities that go on the Internet. In traditional African culture, nudity is still not a virtue. In many African universities and urban centres, nudity has become and Africa's rich and elegant dress style are becoming outdated (Mugambi \& Nasimiyu, 2003).

In Nigeria, fraudsters patronize cyber cafes, browsing all night, sending scam mails to unsuspecting victims. Their activities are carried out in various dimensions, ranging from soliciting for money, illegal businesses and even relationships and marriages. Many foreigners, especially women, who are seeking for spouses via the Internet have been known to have fall victim of the so called 'yahoo boys'. They pretend to be ready to go into a lasting relationship with these women and subsequently start to exploit them. Some of them get their victims to help in procuring travel documents to where they reside or even to assist in getting residential permits for them. Once they have been able to achieve their aims, they stop communicating with the victim and move on to another target. In essence, all the above are a fall out of globalization.

\section{SUGGESTION AND CONCLUSION}

While it is correct to say that globalization has both positive and negative impacts on the world, Nigeria inclusive, its negative impacts are very weighty. There is a need to urgently and effectively address these challenges arising from globalization. Without doubt, globalization is an irreversible process in accord with natural laws. In as much as the pain caused by some aspects of globalization is undeniable, the real issue is whether the negative effects of its sweeping processes can be ameliorated - and the positive effects enhanced. This is because it is apparent that globalization has come to stay.

Therefore, major religious faiths are to be united in the values which espouse the notion of a shared humanity. Fundamentally, this helps to open a framework for dialogue, constructive debate and joint action. This confronts that which is an affront to civilization, namely the persistent scourge of material poverty, and the malaise of bigotry, intolerance and inequity, whether based on religion, nationality, race, culture or gender. To articulate the fundamental perspective of our faith, Christianity is to explicitly affirm the essence of the message revealed to diverse communities. Therefore, the message of universality respects the plurality of religious traditions. This bears glad tidings which have not been passed for emphasis that God sent people to save in the language of his people.

Christian Religion values can be used to foster national development. In Nigeria, political, economic and social development can be promoted through religion. Certain Christian religious beliefs and practices are progressive to development. This is to say that Christianity makes citizens to be conscious of their duties that promote national unity, integration and civic awareness for the common good of all. It has spiritual and hygienic implications that breed people with sound moral and spiritual mind, as part and parcel of social living. Yet, one of the effective options to quench the crises in Nigeria is only to come back to religion, to resolve such conflict situations. 


\section{References}

[1] Adamu, L. Fatima (2003) "Globalization and Economic Globalization in Northern Nigeria". A paper presented at the development studies Association Annual Conference held at Scotland on $9^{\text {th }}-12^{\text {th }}$ September.

[2] Ajeyet, D.N. (2005) "Enhancing a New World Order Through the Religious Moral Integration", Gidan-Waya Journal of Education. Kaduna State College of Education, GidanWaya. Vol. 2 No 3, Page 158-164, ISBN 1119-6801.

[3] Ayuba, C. \& Zakka A.T. (2007) "The Role of Religion in Resolving Inter-Ethnic Conflicts in the $21^{\text {st }}$ Century Nigeria", Journal of the School of Arts and Social Sciences. Gidan-Waya: Kaduna State College of Education. Vol. 1 No. 1, Page 404-418.

[4] Daudu, M. Ed (2005) Contemporary Ethical Issues in Christian Perspective. Zaria: Adex Ventures.

[5] Gotan, C.T. (2005) "Evaluation of christian religious knowledge curriculum for Junior Secondary Schools in Plateau State of Nigeria 1985-2002". A Thesis in the Department of Arts and Social Science Education, Faculty of Education, School of Post Graduate Studies, University of Jos, in partial fulfilment of the Requirements for the award of the degree of Doctor of Philosophy. April, 2005.

[6] Rodrik, D (1997) has globalization gone too far? International Political Economy at Harvard (ISBN 0-88132-243)

[7] Federal Republic Of Nigeria (1992) The Constitution of the Federal Republic of Nigeria 1989. Lagos: Daily Times Nigeria Limited.

[8] Giddens, A. (2006) Sociology. Cambridge: Polity Press.

[9] Horton, P.B. \& Hunt, C.L. (1982) Sociology. London: McGraw-Hill International Book Company.

[10] Mugambi, J. N. K., \& Nasimiyu, A. (Eds.), (2003). Moral and Ethical Issues in African Christianity: A challenge for African Christianity. Nairobi: Action Publishers.

[11] Oyeyinka, A.F. \& Adeniyi, E.O. (2005) "Religion and National Development Under a Democracy: A Critique of its Practice in Nigeria", Journal for the Promotion of Studies in Religion, Education and Languages. Abeokuta: Goad Educational Publishers. Vol.4. No. 1, Page 146-151.

[12] Okpaga, A. (2003) 'The Globalization of Western Cultural Values: Some Implications and Consequences for National Development in Nigeria', Journal of Globalization and International Studies. July - December 2003. Vol. 1. No. 1.

[13] Ozumba, G. O. (1999) 'Nigerian Traditional Moral Values and Philosophy' In Ozumba, G. O., Eteng, O. N., and Okon, M. (eds.) Nigeria: Citizenship Education. Aba: Vitalis Books pp 197-206.

[14] The Holy Bible (Revised Standard Version).

[15] Usman, Y. B. (2004) What Exactly is Globalization? A keynote Address at the Opening Ceremony of the $40^{\text {th }}$ Annual Conference of the Nigerian Association of Law Teachers at the Nigerian Institute of Advanced Legal Studies, University of Lagos on $17^{\text {th }}$ May.

[16] www.nationmaster.com/graph/med-tel-vn-media-television-viewing

[17] www.cellular-news.com/story119223.php 